\title{
A Study on Fintech Based on Actual Cases
}

\author{
Seong-Hoon Lee ${ }^{1}$ and Dong-Woo Lee ${ }^{2 *}$ \\ 'Division of Information \&Communication, Baekseok University, 115, Anseo-dong, \\ Cheonan, Choongnam, Korea \\ ${ }^{2}$ Dept. Of Computer Information, Woosong University, 226-2, Jayang-dong, \\ Dong-gu, Daejon, Korea \\ Ishlee@bu.ac.kr, ${ }^{2} d w l e e @ w s u . a c . k r$
}

\begin{abstract}
It has been changed various patterns related with our consumption because of popularization and progress on mobile device and service. We can buy necessary products anywhere and at any time during 24 hours. Through the change of patterns in our life, in recent years, Fintech attracts a lot of attention. Fintech is the fusion type of finance and technology. Fintech encompasses all technical processes related with financial services including mobile payment and remittance, private asset management and crowdfunding. Industry fields related with Fintech are now proceeding well in America, England and China. Therefore, we studied the issues of Fintech, and described the industrial technology trends in this paper.
\end{abstract}

Keywords: Smart device, Technology, Conversions, Bank, Finance

\section{Introduction}

The Fintech industry recently emerges centered on Silicon Valley. Fintech is a compound of financial and technology, and means the industry in which mobile payment and remittance, asset management and crowdfunding are blended [1-8]. Fintech refers to a newly emerging industry and service fields through the fusion of finance and ICT (information and communications technology) [9]. Fintech encompasses all technical processes related with financial services including mobile payment and remittance, private asset management and crowdfunding [12-13]. Also, Fintech includes technologies affecting financial institutions' overall businesses such as decision making, risk management, portfolio re-construction, law compliance, performance management, system integration and online transfer and payment.

The Fintech industry has naturally emerged in our living pattern change. The emergence background of Fintech can be divided into four areas as follows:

-Change of consumption environment: Because the environment, in which consumer can buy necessary items anytime, anywhere using mobile devices, is shaped without going to offline market, or without sitting in front of a PC to buy goods and services, the consumption market through mobile devices is enormously growing. Consequently, people pay attention to the potential of mobile payment and remittance.

-IT technology development: Due to the development of big data technology that can collect large amount of standard and non-standard data together with mobile technology development, the Fintech area is hugely expanding to credit analysis, loans and asset management beyond just payment.

- Incessant competition of companies: The mobile financial market combined with financial industry continuously grows, due to fierce competition of global IT companies.

*Corresponding Author 
Therefore, global mobile market has been growing over $15 \%$ annually for the past ten years. In China, especially, mobile e-commerce increased more than ten times from 260 billion yuan to 2.79 trillion yuan in five years from 2009 to 2014 .

-Growth limitation of financial market: The Fintech industry gains attention as an alternative to earnings model creation using innovative financial techniques from existing earnings model, owing to the experience of subprime mortgage insolvent loans and financial crisis.

Chapter 2 deals with the actual cases of foreign countries. Chapter 3 of this paper identifies international trends and service types of Fintech that are globally researched and developed, and Chapter 4 describes the study results.

\section{Oversea Cases of Fintech}

The electronic payment (e-payment) market is the currently most competitive market in the Fintech industry. Global IT companies have striven to enter the e-payment market at early stages. Because consumers seldom change a payment system, once they choose one, the companies judged they can take the initiative in the Fintech market, if they dominate the payment market. Many Korean consumers buying goods and services through overseas direct purchase pay in the U.S. dollar using PayPal. Not only PayPal is convenient to use, but money exchange commission ranging $3 \sim 6 \%$ is added, if a consumer uses the Korean payment system and pay in Korean won.

PayPal that was acquired by a U.S. e-commerce company, eBay, launched a convenient payment service (a service through which payment is made with just simple authentication procedure without credit card number everytime, once the credit card information is entered) in 1998, and achieved KRW 180 trillion of payment performance in 2013. PayPal provides a virtual account between a consumer and a seller, respectively, and lets withdrawal and payment made using the account.

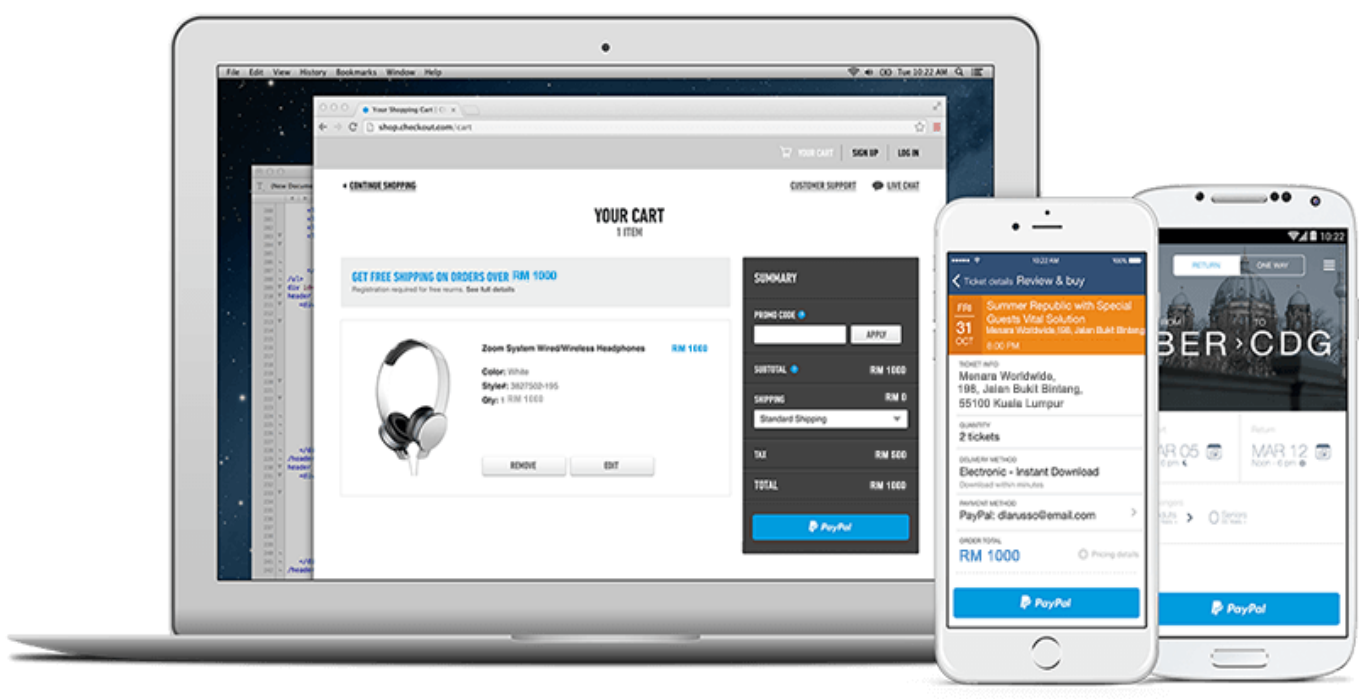

Figure 1. PayPal

Payment is not made directly from a credit card, debit card or bank account under one's own name, but withdrawal is made from the virtual account, whenever payment is needed, after a user puts money in the virtual account provided by PayPal. PayPal expands its business into various following financial areas including such a convenient payment service: PayPalHere service, PayPal prepaid card service May Cash, PayPal credit service offering short-term loans in relation with goods purchase, and money transfer service that targets EU member countries. 
After Amazon had applied one click payment system to its Website, the company expanded payment areas by adopting "Login and Pay with Amazon" service in 2013. Also, remittance between individuals using email address is supported as well.

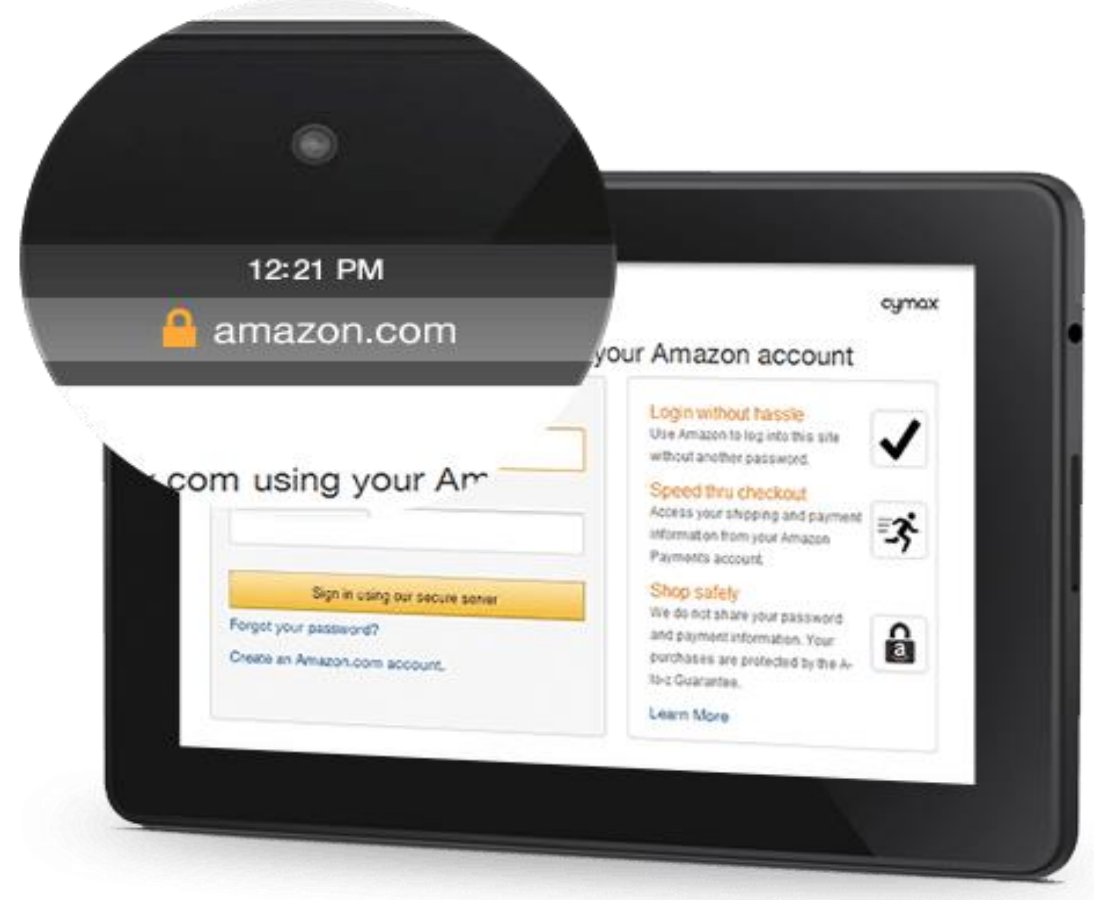

Figure 2. Amazon Payment

Apple officially launched an e-payment service, Apply Pay service, using NFC (near field communication) in 2014 [4-5]. This method is that payment is automatically made, when a user touches his/her finger at Touch ID, a fingerprint sensor, after a user contacts iPhone with the payment terminal.

Apple stores key payment information including credit card number by encoding it within iPhone, not Apple's server.

Because, 16-digit virtual number is used for payment, not credit card number, security is excellent without conveying credit card information to sellers. Extraordinarily, Apple has established alliance with major distribution companies with 220,000 outlets including Walgreen, and Macy's, as well as banks such as the Bank of America.

Credit card companies including Visa and Amex taking up 90\%, based on use amount in the U.S., have become the partners of Apple. 


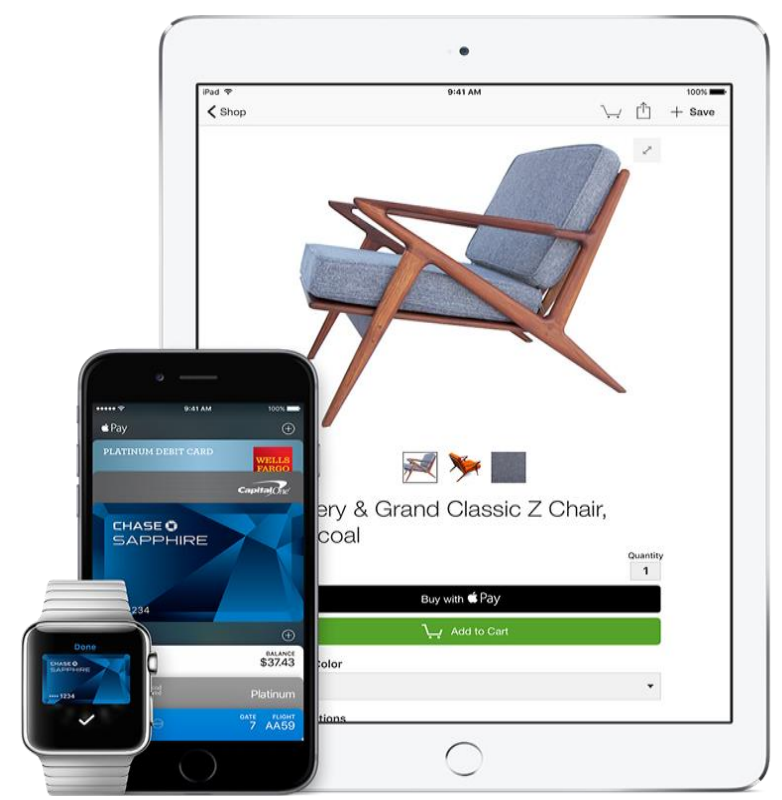

Figure 3. Apple Pay

Google released Google Wallet, an e-payment service using NFC in 2011, and the City Bank, Master Card, Samsung Electronics and Sprint participated in the service. Although, Google adopted the e-payment service ahead of other competitors, payment can be made with the devices of No. 3 communication carrier, Sprint, due to resistance of local communication carriers. Actually, Google's e-payment service struggles, because of small number of member merchants, and is contrasted with Apple Pay. Google added a function to remit money through email in Google Wallet in 2013. It has a function to send money through encoding, as if an attached file was added using Gmail.

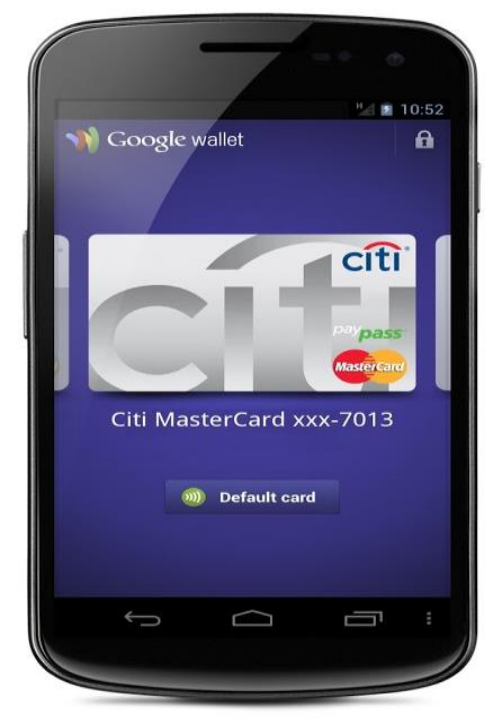

Figure 4. Google Wallet

China's e-commerce company, Alibaba, started AliPay, which is a financial service used in PC and mobile devices, in 2003. AliPay supports customers to pay almost everything such as buying goods and services, paying taxes \& dues and transportation fares, and offline shopping using an AliPay account, after a customer charges the account with cash or credit card. Fund transfer is possible, and loans or fund consulting can be 
received. The number of AliPay members was 820 million, based on July 2014, and AliPay takes up $50 \%$ of the online payment market in China.
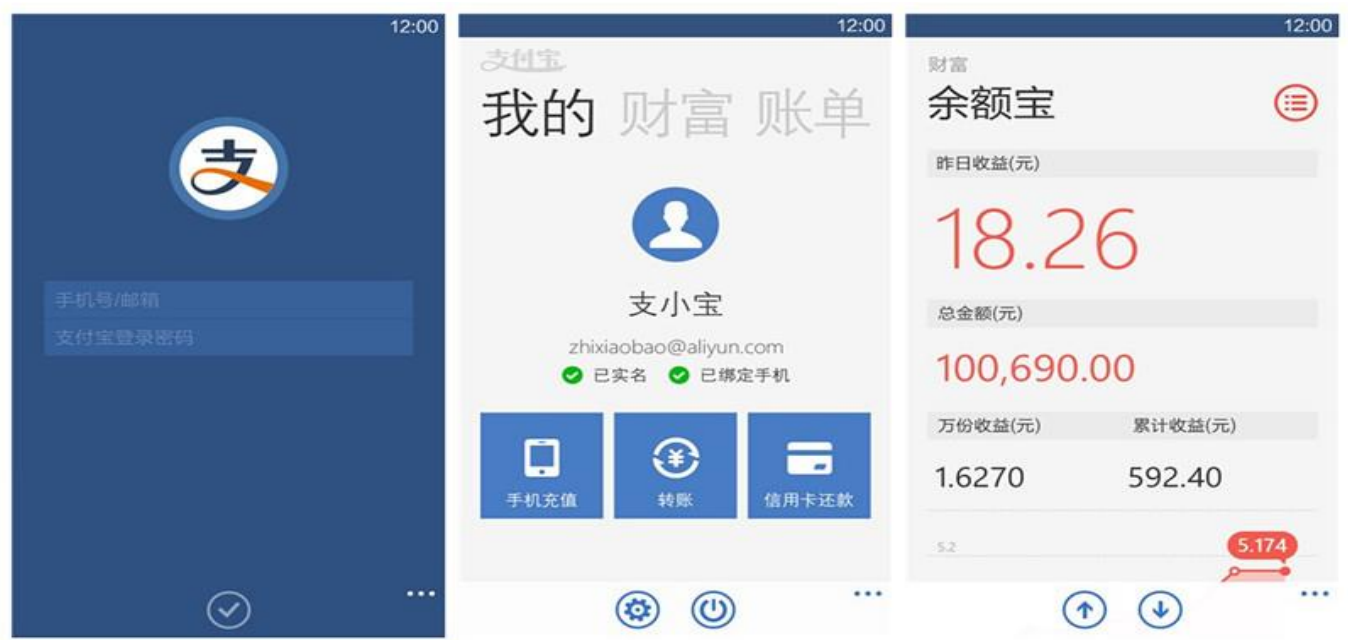

Figure 5. AliPay

Meanwhile, existing banks offer new financial services using Fintech technology. Some cases concerned are presented below: British Barclays, which established an Internet Bank, launched a financial App, Ping It in 2012, offering e-wallet payment service and telephone number-based remittance service. As of February 2014, 2.5 million users downloaded Ping It, and the service is widely used as such. Several banks including HSBC have adopted a convenient mobile payment service in alliance with Zapp, a Fintech company. The system is a service enabling mobile payment convenient with just entering password, and the 11 stages required for payment were reduced to four stages.

German Fidor Bank has introduced a new concept inducing customers' participation by combining IT and online media. In this system, customers can post their opinions on new product idea, evaluation on existing products, financial technique consulting and advice using the online homepage. According to customer's participation type, various incentives are offered. A new customer can apply for an account through Facebook Connect. In the U.S., a financial group, Capital One, has acquired an Internet bank, ING Direct, and operates an online bank utilizing Fintech.

\section{Predictions and Service Types of Fintech}

The most used area in the Fintech industry is the electronic payment sector using mobile devices. As $\mathrm{O} 2 \mathrm{O}$ (online-to-offline) business grows globally, the online payment market grows together, which is the result of IT technology's combination with finance. Global mobile payment market was expanded from USD 52.9 billion in 2010 to USD 235.4 billion in 2013 , namely, more than four times, and the market is forecast to grow to USD 720 billion in 2017. Following Figure 6 reveals the prospect of global mobile payment market predicted by Gartner. Gartner, a market research company, forecasted the global mobile payment market will grow from KRW 300 trillion in 2014 to KRW 800 trillion in 2017 with annual growth rate of 30 40\%. 


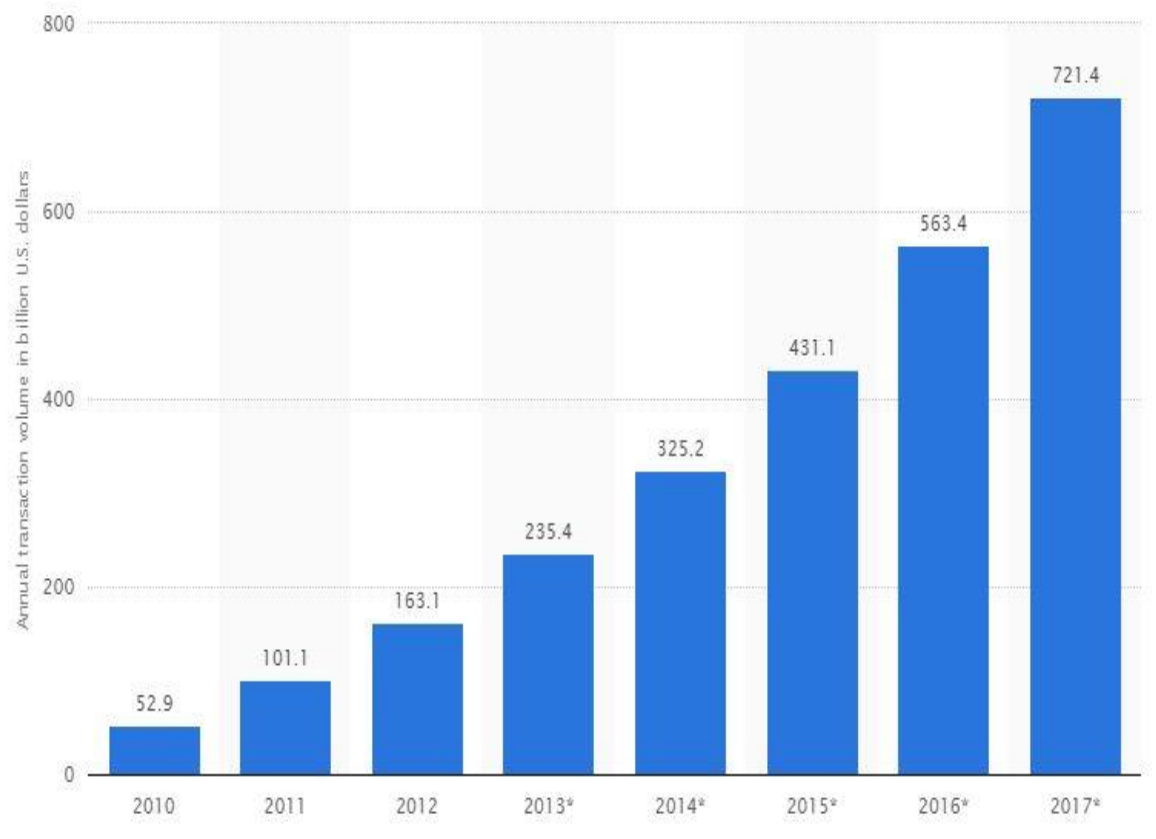

Figure 6. Prospect of Global Mobile Payment Market

Looking at Fintech trends in foreign countries, independent financial services are provided in Britain and Europe using Fintech technologies, centered on existing banking sector, which is a traditionally powerful player. Meanwhile, non-financial companies' entry into the Fintech industry, centered on global IT companies such as Alibaba, is actively carried out in China.

Although, Fintech was mainly used as such functions as mobile payment and remittance at its early stage, it gradually expands its service areas into credit analysis and loans. In 2008, $70 \%$ of Fintech-related investment was concentrated on payment. However, payment took up only $28 \%$ in 2013, due to rapid increase of investment ratios of data analysis and corporate finance. Table 1, 2, 3, 4 show Fintech service types.

Table 1. Fintech Service Type- Payment

\begin{tabular}{|c|c|c|}
\hline Service Type & Case & Details \\
\hline Payment & $\begin{array}{l}\text { - Google Wallet } \\
\text { - PayPal } \\
\text { - Alipay } \\
\text { - Apple Pay }\end{array}$ & $\begin{array}{l}\text { - Offers a payment service of which use is simple } \\
\text { and imposes low charges. } \\
\text { - E-payment service supporting for payment to be } \\
\text { made simply using user's pre-registered card or } \\
\text { account information, when a user purchases goods } \\
\text { and services. } \\
\text { - Because, the service type is in alliance between } \\
\text { Fintech business and existing financial companies } \\
\text { including banks and credit card companies, the } \\
\text { services familiar to users such as NFC and } \\
\text { electronic wallet continuously appear. } \\
\text { - Global e-payment amount is predicted to reach } \\
\text { USD } 700 \text { billion by } 2017 \text {. }\end{array}$ \\
\hline
\end{tabular}


Table 2. Fintech Service Type- Remittance/e-Money

\begin{tabular}{|c|c|c|}
\hline Service Type & Case & Details \\
\hline $\begin{array}{l}\text { Remittance/e- } \\
\text { money }\end{array}$ & $\begin{array}{l}\text { - Bitcoin } \\
\text { - M-Pesa } \\
\text { - TranserWise }\end{array}$ & $\begin{array}{l}\text { - E-payment service supporting for } \\
\text { payment to be made simply using user's pre- } \\
\text { registered card or account information, when } \\
\text { a user purchases goods and services. } \\
\text { - E-money with which online transaction } \\
\text { is made. This generally refers to newly } \\
\text { emerged money including bitcoin and the } \\
\text { money assisting existing money's payment } \\
\text { means such as M-Pesa. } \\
\text { - Remittance service between individuals } \\
\text { and companies can be included, in addition } \\
\text { to e-money. }\end{array}$ \\
\hline
\end{tabular}

Table 3. Fintech Service Type- Data Analysis

\begin{tabular}{|l|l|l|}
\hline Service Type & \multicolumn{1}{|c|}{ Case } & \multicolumn{1}{c|}{ Details } \\
\hline Data analysis & $\begin{array}{l}\text {-Affirm } \\
\text { - Mint.com }\end{array}$ & $\begin{array}{l}\text { - Creates new added value by collecting and } \\
\text { analyzing a variety of personal and corporate } \\
\text { customers-related data. }\end{array}$ \\
\hline
\end{tabular}

Table 4. Fintech Service Type- Platform

\begin{tabular}{|c|l|l|}
\hline Service Type & \multicolumn{1}{|c|}{ Case } & \multicolumn{1}{c|}{ Details } \\
\hline Platform & - AngelList & - Online platform providing financial service \\
- Lending Club & - OnDeck & $\begin{array}{l}\text { such as loans and start-up funding support. } \\
\text { - Financial investment platform's market } \\
\text { share increases with low charges, quick } \\
\text { transfer and user-friendly interface, } \\
\text { compared with existing financial system. } \\
\text { High repayment ratio and low accident ratio } \\
\text { are shown, compared with the existing } \\
\text { financial service by analyzing user credit } \\
\text { rating, based on big data }\end{array}$ \\
& $\begin{array}{l}\text { - Online platform is recognized as a fund } \\
\text { provider for the companies not receiving } \\
\text { existing financial service like start-ups and } \\
\text { medium and small businesses (SMBs). The } \\
\text { online platform is used as growth engine for } \\
\text { activation of SMBs and start-ups. }\end{array}$ \\
\hline
\end{tabular}

As Fintech was gradually expanded from the initial stage of mobile payment and remittance to credit analysis and loan areas, big data technology began to be combined with Fintech. A New York-based start-up, OnDeck, offers loan service online without offline service, and loan screening process is completed in about 15 minutes. Insolvency ratio is less than $5 \%$, and this is possible, because user's bank transaction details and credit rating are quickly analyzed through big data. OnDeck is the online credit bank and targets many small traders. And its scale enlarges every year from 2007 to 2015 . Figure 7 shows principle of OnDeck. 


\section{Our Principles}

$>$ We believe small businesses are the key to local economic success and deserve an easy and inspiring lending experience.

> We know time is money, and our products and services are designed to keep owners moving at the speed of business.

We make sure that our loan costs and terms are transparent and understandable.

> We know that having someone to speak with about financing is important, so we have US-based Lending Specialists available to answer any questions.

\section{Figure 7. Principles of OnDeck}

Figure 8 shows loan amount per year from 2007 to 2015. Loan size increases every year.

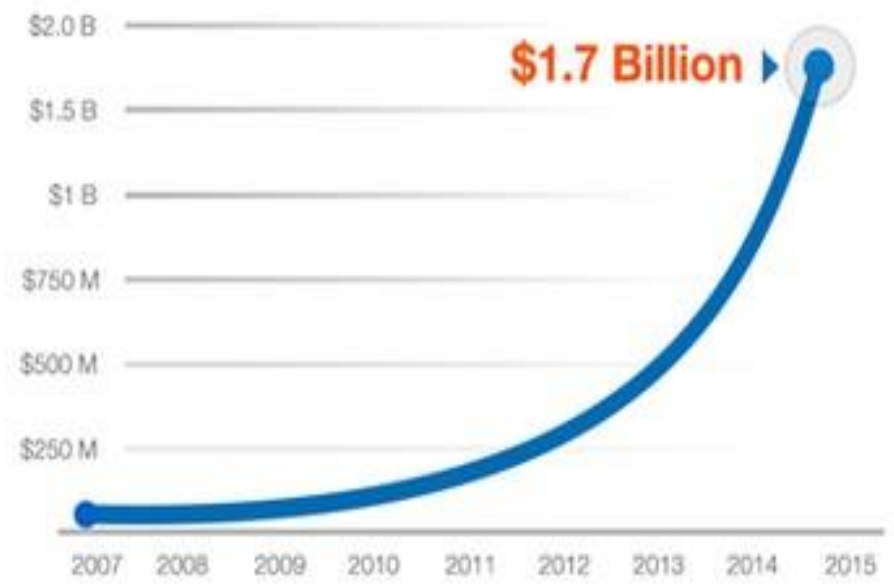

Figure 8. Loan Scale from 2007 to 2015

\section{Conclusions}

Fintech is a compound of financial and technology, and means the industry in which mobile payment and remittance, asset management and crowdfunding are blended. Fintech encompasses all technical processes related with financial services including mobile payment and remittance, private asset management and crowdfunding.

The most used area in the Fintech industry is the electronic payment sector using mobile devices. As $\mathrm{O} 2 \mathrm{O}$ (online-to-offline) business grows globally, the online payment market grows together, which is the result of IT technology's combination with finance. Global mobile payment market was expanded from USD 52.9 billion in 2010 to USD 235.4 billion in 2013, namely, more than four times, and the market is forecast to grow to USD 720 billion in 2017.

Fintech is gradually expanded from the initial stage of mobile payment and remittance to credit analysis and loan areas, big data technology began to be combined with Fintech. 


\section{References}

[1] B. G. Kim, “Trend and lessons of FinTech”, GRI, (2015).

[2] G. S. Lee, "Current Trend and Case of combining with FinTech", KBFG, (2014).

[3] http://www.apple.com/apple-pay/

[4] "Apple Announces Apple Pay", http://www.apple.com/pr/library/2014/09/09Apple-Announces-Applepay.html, (2014).

[5] "How Apple Pay is designed to avoid the pitfalls of traditional payment systems", http://appleinsider.com/articles/14/10/20/, (2014).

[6] A. Irrera and S. Krouse, "Race to be the big wheel in Fintech," FinancialNews, (2014).

[7] B. Chris and G. Daniel, "Fintech: Building a $21^{\text {st }}$ Century regulators Toolkit", Milken Institute, (2014).

[8] D. Colin, "Will technology eat our banks?", Heraldscotland, (2014).

[9] G. Robert and G. Maria, "The Rise of Fintech-New York's Opportunity for tech Leadership", Accenture, (2014).

[10] S. Julian, "The Boom in Global Fintech Investment", Accenture, (2014).

[11] D. McAuley, "What is FinTech?", Wharton FinTech, (2014).

[12] J. Eyers, "FinTech Heats up Competition with the youngest and fittest", Australian Financial Review, (2015).

[13] B. Leimer, "So What is FinTech,", NDRC, www://www.ndrc.ie/, (2014).

[14] C. Sanati, "How Future Advisor Plans to shake up Wealth management", Fortune, (2014).

[15] Y. Lin, C. Zhong and Y. Liu, "Research on Traffic Journey Intensity of Residents based on Gravity Model" IJSH, vol. 9, no. 11, (2015) , pp. 99-110.

[16] H. Zhang, "Distributed Localization Algorithm for Large-scale Wireless Sensor Network", IJSH, vol. 9, no. 10, (2015) , pp. 233-242.

[17] C. S. Ryu, "Iot-based Intelligent for Fire Emergency Response Systems", IJSH, vol. 9, no. 3, (2015), pp. $161-168$.

[18] http://payments.amazon.com.

\section{Authors}

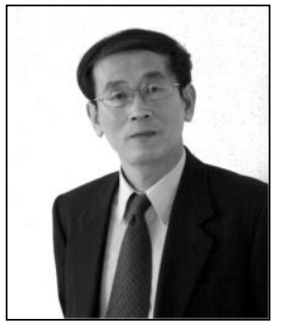

Seong-Hoon Lee, (MSc'95-PhD.'98) He received the M.Sc. degree of Computer Science and Engineering from Korea University, Seoul, Korea in 1995, and the Ph.D. degree of Computer Science and Engineering from Korea University, KOREA in 1998. Since 1998, he is a Professor in School of Information and Communication, BaekSeok University, Korea. His main research interests include Distributed system, Grid Computing, Web Service, etc.

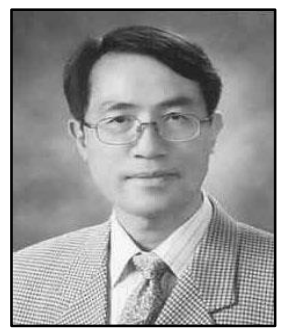

Dong-Woo Lee, he received his BS in electronic engineering, MS in computer engineering, and $\mathrm{PhD}$ in computer science from Korea University, Korea. He joined the department of computer information science, Woosong University, Korea at 1995. He is currently a professor. His research interests include distributed processing and systems, database, and reactive systems. (Corresponding author of this paper) 
International Journal of $u-$ and e- Service, Science and Technology Vol.9, No. 8 (2016) 